\title{
Neurotoxic Effects Associated with Current Uses of Organophosphorus Compounds
}

\author{
Iris Mangas, ${ }^{*, a}$ Eugenio Vilanova, ${ }^{b}$ Jorge Estévez ${ }^{c}$ and Tanos C. C. França ${ }^{*, a, c, d}$ \\ ${ }^{a}$ Laboratório de Modelagem Molecular Aplicada a Defesa Química e Biológica (LMCBD), \\ Instituto Militar de Engenharia, 22290-270 Rio de Janeiro-RJ, Brazil \\ ${ }^{b}$ Toxicology and Chemical Safety Unit, Miguel Hernández University, Elche, Spain \\ ${ }^{c}$ Center for Basic and Applied Research, Faculty of Informatics and Management, \\ University of Hradec Králové, 50003 Hradec Králové, Czech Republic \\ ${ }^{d}$ Department of Chemistry and Biochemistry, Concordia University, H4B 1R6 Montreal-QC, Canada
}

\begin{abstract}
Organophosphorus compounds (OPs) are a large and diverse class of chemicals that have been synthesized, since the XIX century for several purposes like chemical weapons, flame-retardants, ectoparasiticides and investigational new drugs, but mainly as agrochemicals in agriculture and indoor. Although the amount of OP pesticides being used is declining, especially in developed countries, OPs continue being one of the most important classes of insecticides and chemical warfare agents today due to its toxic effects on the enzyme acetylcholinesterase (AChE). Existing research on the toxicological effects of OPs is extensive, however, there is a lack of knowledge on the long-term effects of low levels of OPs and their exactly pathways of toxicity. Recent data prove that other molecular targets than AChE could be targeted by OPs, triggering these effects. Here these data are reviewed and it is highlighted that the current uses of OPs are producing several neurotoxic effects. It is also shown that, to protect people from possible uses and misuses of OPs, more regulations on OPs are needed. Moreover, more mechanistic studies are needed to completely understand their toxicological interactions and mechanisms of action and to identify the whole group of enzymes that interact with them.
\end{abstract}

Keywords: organophosphorus compounds, toxicological aspects, pesticides, chemical weapons, esterases

\section{Current Uses of Organophosphorus Compounds}

Organophosphorus compounds (OPs) are a large and diverse class of chemicals. The first OP, tetraethyl phosphate, was synthesized by Philippe de Clermont, in France in 1854, and OP esters were discovered as toxicants for people in 1932, when Lange and Kruger described the synthesis of dimethyl and diethyl phosphofluoridate and reported that the inhalation of its vapors produced dimness of vision and a choking sensation. In 1937, Gerhard Schrader was synthesizing OPs for the I. G. Farbenindustrie, in Germany, to be used as pesticides, and one of the earliest was parathion. ${ }^{1}$ Before World War II (WWII), the Germans priority turned from pesticides to chemical warfare agents, and considerably more toxic OP were synthesized. Since then

*e-mail: imangas@umh.es; tanos@ime.eb.br it is estimated that hundreds of OPs have been synthesized for various purposes. During the second half of the XX century, $\mathrm{OP}$ esters became very popular worldwide because organochlorine pesticides were found to persist in the environment. This extended the development of resistance by insects to the chlorinated hydrocarbon insecticides. ${ }^{2-5}$ Pesticide manufacturers, then, concentrated on phosphoric acid esters for the simple reason that they are somewhat easier to synthesize, hence, less costly to manufacture. For many decades, OPs have been major insecticides in terms of their number and market share. They were the first highly effective and systemic ones, able to move throughout plants to protect even the growing tip from sucking insect pests for several days or weeks.

The selective toxicity of OP pesticides is based on specific differences in cholinesterase (ChE) targets, more rapid detoxification in mammals than in insects and in the use of pro-insecticides which are activated in insects 
better than in mammals. Their easy biodegradation and low environmental persistence, compared with organochlorine, come together with toxic effects, which are more likely due to acute rather than chronic exposure. ${ }^{6-8}$

The amount of OPs pesticides in use today is declining, especially in developed countries. Since 1997, there has been a market shift from OPs and carbamates to pyrethroids and neonicotinoids, together with a variety of non-neuroactive pesticides as biological agents or juvenile hormone analogues. ${ }^{9}$ For example, in the United States, the amount of OPs insecticides used has dropped by more than $60 \%$ since 1990 from an estimated 85 million pounds in 1990 , to 33 million pounds in 2007 when OPs accounted for about $35 \%$ of the insecticides used. Despite the number of compounds acting in other targets than ChEs have increased in the last three decades, OPs and methyl carbamates remain at the top of the list among commercial insecticides ${ }^{10}$ and their importance will probably continue for decades, since they are effective and inexpensive. ${ }^{11}$

Moreover, OPs continue to be on the focus of great research efforts. For example, a medline search made by Costa, ${ }^{12}$ in August 2005, with the terms organophosphate/ organophosphorus, provided around 5,000 hits since the year 2000. When we repeated their approach in December 2015, more 5,500 hits were found since the year 2010. The reasons for these efforts in research activities are the continuous high worldwide use of these compounds as pesticides, especially in developing countries, the uses of OPs as chemical weapons in the last years in Syria and some important questions on their mechanisms of toxicity that need to be clarified, especially in relation to their long term neurotoxicity effects and the existence of non-cholinergic targets in mammals.

Costa $^{12}$ pointed out 6 priority questions to answer in 2006: (i) does OPs exposure result in behavioral and neuropsychology toxicity in humans? (ii) Is there genetic susceptibility to OPs? (iii) Are children more sensitive to OP toxicity than the rest of the population? (iv) Do all OPs have the same mode of action? (v) What are the precise molecular events involved in the organophosphorus induced delayed neuropathy (OPIDN)? And (vi) are additional targets of OPs relevant for some of these effects? In this work, we provide answers to some of these questions in the light of the new published data. ${ }^{12}$

Brazil is the largest consumer of pesticides in South America, with $19 \%$ of the world consumption and 35 approved in the current legislation. Together with carbamates, OPs represent the main classes used and had been the major responsible for lethal intoxications in the country. ${ }^{13}$ Moreover, in Brazil it is still common the misuse of OP and carbamate insecticides of restrict agricultural use as household biocides (mainly aldicarb) regionally known as chumbinho. ${ }^{14,15}$ There are several risks involved with inappropriate use of these substances, such as occupational, environmental and some issues related to food safety. It is clear that pesticides intoxication is a current serious problem in Brazil, but there is limited information regarding the exact magnitude of the problem, the management and outcomes of poisoned patients, and the long term toxicity effects of these compounds in the country due to the lack of data on biomarkers of exposure identifying the type of compound responsible for the intoxication. ${ }^{16,17}$ As an example, in 2011, the last year with data published from the national system of toxico-pharmacological information, ${ }^{18}$ there were reported 11,106 cases of pesticide poisoning in 23 of the 34 poisoning control centers spread out in the country. Among these cases, $158(1.42 \%)$ resulted in deaths. Accidental poisoning was involved in 4,450 cases $(40.1 \%)$, suicide attempts in $4,591(41.3 \%)$ and occupational poisoning corresponded to 1,313 cases $(11.8 \%) .{ }^{18}$

In the USA, with $17 \%$ of the world compsumption, ${ }^{12}$ there are more data on biomarkers of exposure and effect of OPs. ${ }^{19}$ Reports showed that $50 \%$ of individuals have measurable levels of the OP metabolite dialkyl phosphate and $71 \%$ of the OP metabolite diethylphosphate. The United States Department of Agriculture (USDA) reported in 2006 that approximately $73 \%$ of fresh fruits, $66 \%$ of vegetables, $61 \%$ of processed foods and $66 \%$ of drinking water in the USA contained detectable levels of OPs. ${ }^{20}$

OPs have also evolved into the principal chemical warfare agents and since the 1980s, they have been used in wars and by dictators and terrorists (for a review on this topic see reference 21). OPs as chemical weapons can be divided into two general types: the $\mathrm{G}$ and $\mathrm{V}$ agents. The most known G agents: sarin (GB), soman (GD) and tabun (GA), were developed in Germany shortly before or during WWII and possess two oxygen atoms bonded to phosphorus (Table 1). The most known $\mathrm{V}$ type agent, VX, is an alkylphosphonothiolate developed in 1952, by the British chemist Ranajit Ghosh, and contains sulfur, as well as two oxygens, bonded to phosphorus. $\mathrm{V}$ agents are less volatile, hence more persistent, had a lower vapor pressure, and a higher viscosity than the $G$ agents, and are 1,000 times more toxic. Unfortunately, there are currently extensive stockpiles of neurotoxic OPs worldwide, which mean a continuous threat. ${ }^{22}$ The potentiality of attacks employing these agents gives a strong reason for continuous research on OPs and the development of more effective means of protection against them. The Organization for the Prohibition of Chemical Weapons $(\mathrm{OPCW})$ estimates that on September $30^{\text {th }}$ of 
2010, there were nearly 30,000 metric tons of nerve agents undestroyed in the world, and these numbers did not include the stockpiles of non-member states that had neither signed nor acceded to the Chemical Weapons Convention (CWC)..$^{21-28}$

In a terrorist attack with GB occurred in a residential area of the city of Matsumoto, Japan, on June $27^{\text {th }}$ of 1994, 600 people were poisoned; 58 were hospitalized and 7 died. ${ }^{29}$ On March $20^{\text {th }}$ of 1995 , another terrorist attack using GB occurred in the Tokyo subway, when 12 people died and more than 5,000 were injured. ${ }^{30,31}$ On the night of August $21^{\text {th }}$ of 2013, GB was dispersed in the eastern outskirts of Damascus, Siria, killing 1,400 civilians and severely affecting thousands more. ${ }^{32-34}$

OPs are also used as anthelmintics and ectoparasiticides in veterinary medicine. The OP trichlorfon (metrifonate) has been used to treat mild and moderate Alzheimer's disease (AD) and as an investigational new drug. ${ }^{35,36}$

Furthermore, halo alkyl phosphates are used as flame retardants, as for example tris (1,3-dichloro-2-propyl) phosphate (TDCPP) and tris (1-chloro-2-propyl) phosphate (TCPP). These compounds do not possess anti-ChE activity.

\section{The Chemistry of OPs}

Chemically OPs are esters of phosphoric acid and its derivatives with varying combinations of oxygen, carbon and sulfur or with nitrogen attached. The general chemical structure of an OP (Table 1) comprises a central phosphorus atom with a double bound to oxygen or sulfur, where $R_{1}$ and $R_{2}$ are commonly alkyl or aryl groups bound to the phosphorus atom either through an oxygen or sulfur (phosphrothioates) or directly (phosphonates or phosphinates). Symbol X represents a variety of groups and is called the leaving group, which is replaced (usually by nucleophilic substitution) by the oxygen of the serine residue at the target protein active site. There are at least 13 types of OPs (summarized in Table 1). ${ }^{37}$
Table 1 (line 1) shows the basic structure of a typical OP, where $R_{1}$ and $R_{2}$ are equaling methyl, ethyl or isopropyl. It has been observed that increasing the alkyl chain leaves the molecule void of insecticidal activity, ${ }^{38,39}$ then X group must vary in the different types of OPs. The number of this activating group seemed to be limitless. In 1958 three dozen compounds were cited to be commercial from that the phosphate and phosphinate esters can give rise to 1,250 potential compounds, while, for making the thionate analogues, the number is doubled..$^{40-42}$

Thus, OPs vary extremely in chemical structure and also in chemical properties (Table 1). OPs can be miscible with water, but more typically are miscible with organic solvents; Table 1 also shows the octanol-water partitioning coefficients of some OPs. ${ }^{43-45}$

\section{Inhibition and Reactivation of Esterases and Cholinesterases by OPs}

Esterases as well as cholinesterases, catalyze the hydrolysis of a carboxylester substrate by a reaction which involves the formation of a covalent acyl-enzyme intermediate with the release of a leaving group. OPs exert their mechanism of toxicity by the covalent organophosphorylation of esterases and cholinesterases. The resulting phosphorylated enzyme is usually very slowly cleaved, or not at all, and remains inhibited. In some cases, the recovery by spontaneous reactivation may occur at a significant speed ${ }^{46}$ or be forced by nucleophilic reagents such as fluoride or oximes (Figure 1). Besides, the phosphoryl enzyme can undergo a dealkylating reaction called aging. ${ }^{47}$ The negative charge of the aged phosphoryl group is more stable and this makes the enzyme not reactivable anymore, either spontaneously or by a reactivating agent (Figure 1).

Oximes can reactivate the phosphorylated cholinesterase in a two steps reaction where: (i) the oxime approaches to the phosphyl group and (ii) forms a fully reversible Michaelis-type conjugate, followed

Table 1. Types of the most common organophosphorus compounds (OPs) used as pesticides and chemical weapons

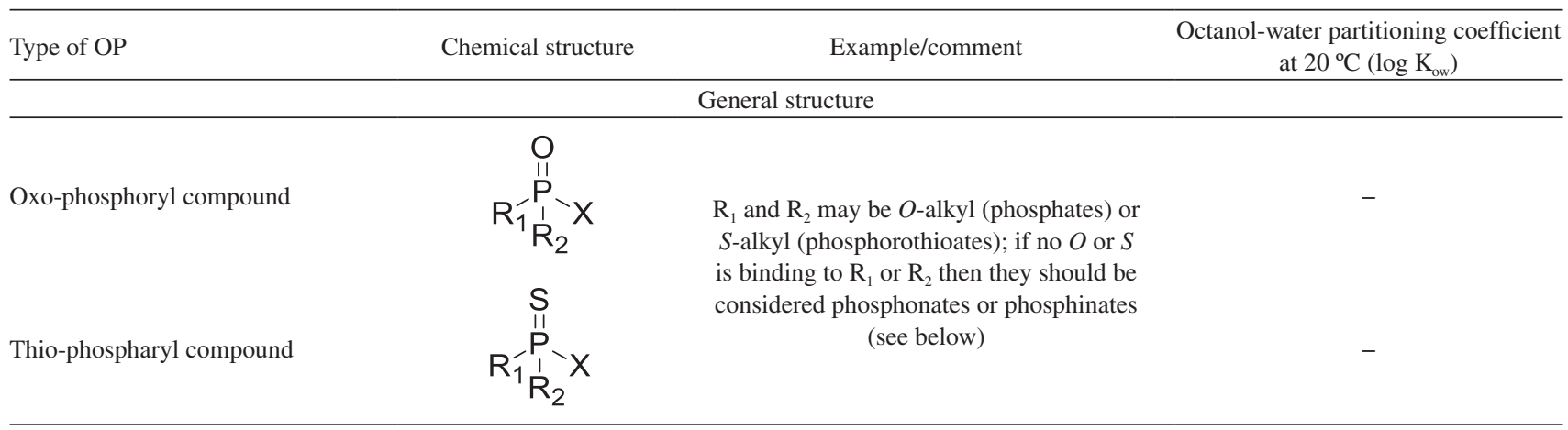


Table 1. Types of the most common organophosphorus compounds (OPs) used as pesticides and chemical weapons (cont.)

\begin{tabular}{|c|c|c|c|}
\hline Type of OP & Chemical structure & Example/comment & $\begin{array}{c}\text { Octanol-water partitioning coefficient } \\
\text { at } 20^{\circ} \mathrm{C}\left(\log \mathrm{K}_{\mathrm{ow}}\right) \\
\end{array}$ \\
\hline \multicolumn{4}{|c|}{ Phosphate } \\
\hline$O, O$ ' Dialkyl-phosphate & $\mathrm{OR}_{1}^{-\mathrm{P}_{1}^{\mathrm{P}}-\mathrm{OX}}$ & $\begin{array}{l}\text { chlorfenvinphos, dichlorvos, monocrotophos, } \\
\text { tri- } O \text {-cresyl phosphate }\end{array}$ & dichlorvos: $1.471^{45}$ \\
\hline \multicolumn{4}{|c|}{ Thiophosphate } \\
\hline$O, O$ ' Dialkyl thiophosphate & $\mathrm{OR}_{1}^{-\mathrm{P}} \stackrel{\mathrm{S}}{\mathrm{II} X}$ & bromophos, chlorpyrifos, diazinon & $\begin{array}{l}\text { chlorpyrifos: } 4.961^{45} \\
\text { diazinon: } 3.806^{45}\end{array}$ \\
\hline$O, O$ ' Dialkyl phosphorodithioate & $\mathrm{OR}_{1}^{-} \mathrm{P}_{\mathrm{I}}^{\mathrm{S}}-\mathrm{SX}$ & methidathion, malathion, dimethoate, disulfoton & malathion: $2.938^{45}$ \\
\hline$O$-Alkyl, $S$-alkyl phosphorodithioate & $\mathrm{R}_{1} \mathrm{~S}^{-} \stackrel{\substack{\mathrm{S} \\
\mathrm{O}_{1}^{-}}}{\mathrm{O}} \mathrm{R}_{2}$ & protiophos, sulprophos, phosmet & phosmet: $2.783^{45}$ \\
\hline \multicolumn{4}{|c|}{ Phosphorothioate } \\
\hline$O, O$ ' Dialkyl phosphorothioate & $\mathrm{OR}_{1}^{-P} \mathrm{OR}_{2}^{\mathrm{I}}-\mathrm{SX}$ & amiton, omethoate & triazophos: $3.551^{45}$ \\
\hline$O$-Alkyl, $S$-alkyl phosphorothioate & $\mathrm{R}_{1} \mathrm{~S}^{-} \stackrel{\mathrm{O}}{\stackrel{\mathrm{II}}{\mathrm{P}} \mathrm{OR}_{2}^{-} \mathrm{OX}}$ & profenophos, trifenophos & temephos: $5.955^{45}$ \\
\hline \multicolumn{4}{|c|}{ Phosphoroamidate } \\
\hline$O, O$ ' Dialkyl phosphoramidate & $\mathrm{OR}_{1}^{-\mathrm{O}}{ }_{\mathrm{O}}^{\mathrm{P}} \mathrm{OR}_{2}^{-\mathrm{NR}_{2}}$ & cruformato, fenamiphos & fenamiphos: $3.227^{45}$ \\
\hline$O$-Alkyl, $S$-alkyl phosphorothioamidate & $\mathrm{OR}_{1}^{-\stackrel{\mathrm{O}}{\mathrm{I}}-\mathrm{SR}_{2}^{-N_{2}}}$ & methamidophos & - \\
\hline$O, O$ ' Dialkyl phophorothioamidate & $\mathrm{OR}_{1}^{-\mathrm{S}} \mathrm{OR}_{2}^{\mathrm{P}} \mathrm{NR}_{2}$ & isofenphos & isophenphos: $4.121^{45}$ \\
\hline \multicolumn{4}{|c|}{ Phosphonate } \\
\hline$O$, Alkyl, alkyl phosphonate & $\mathrm{OR}_{1}^{-} \stackrel{\mathrm{O}}{\mathrm{P}} \mathrm{R}_{2}^{1}$ & $\begin{array}{l}\text { triclorphon (phosphonates = one of the } \mathrm{R} \text { groups } \\
\text { is not bound to the } \mathrm{P} \text { thorough an } \mathrm{O} \text { atom) }\end{array}$ & triclorphon: $0.431^{45}$ \\
\hline Dialkyl phosphonate & $\mathrm{R}_{1}^{-} \stackrel{\mathrm{O}}{\mathrm{O}} \mathrm{R}_{2}^{\mathrm{P}} \mathrm{OX}$ & gluphosinate & - \\
\hline$O$, Alkyl, alkyl phosphonothioate & $\mathrm{OR}_{1}^{-} \stackrel{\mathrm{O}}{\mathrm{I}} \mathrm{R}_{2}^{-} \mathrm{SX}$ & VX (chemical warfare agent) & VX: $2.06^{44}$ \\
\hline
\end{tabular}


Table 1. Types of the most common organophosphorus compounds (OPs) used as pesticides and chemical weapons (cont.)

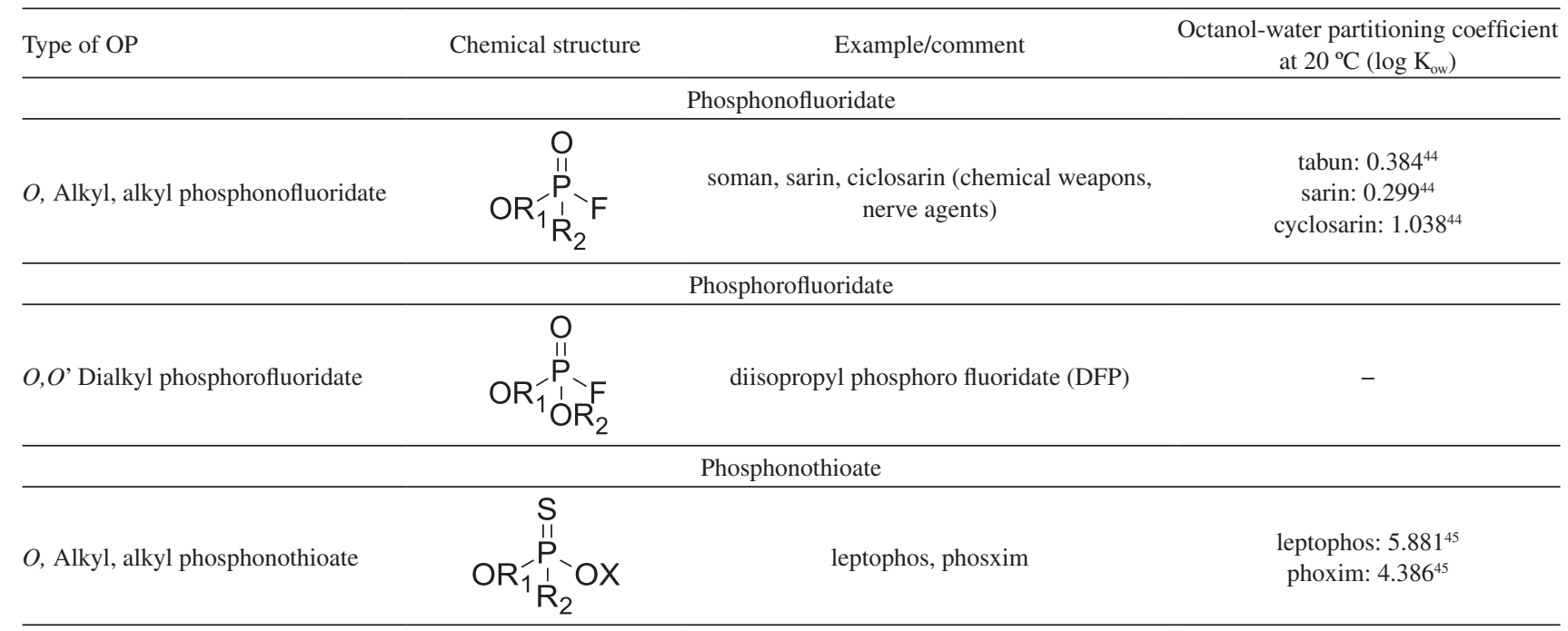

by the displacement of the phosphyl residue (Figure 1). In the last years, extensive research has been done using molecular modeling, X-ray crystallography, cholinesterase mutants, nuclear magnetic resonance (NMR) and mass spectrometry, in order to provide a better understanding of these reactions in the molecular level. ${ }^{48-56}$ Furthermore, several research programs were initiated in many countries for the development of oximes. However, regardless the greatest effort until now, only few oxime-based reactivators are used for treatment of human OP poisoning, namely pralidoxime, obidoxime and TMB-4. ${ }^{57-60}$ Despite structurally oximes have a high structural diversity, they are nevertheless, characterized by four common basic structural characteristics: (i) charged or non-charged one or two ring systems (e.g., pyridinium, imidazole); (ii) ring(s) bearing one or more, symmetric or asymmetric oxime groups at positions 2, 3 or 4; (iii) aliphatic or aromatic side ligands attached to the ring(s); and (iv) different linkers between the rings (Figure 2). Currently, research in the design of new types of oximes is crucial to have a therapeutic solution to OPs intoxication. The main current focus in the development of oximes is to improve the blood-brain-barrier penetration for a more efficacious reactivation of inhibited brain AChE. ${ }^{61-63}$ Increasing research can also be found in the area of new compounds with a mechanism not related to the AChE reactivation. Some results suggest that bisquaternary compounds have an additional therapeutic action in vivo, more effective and less toxic. It has been demonstrated that some oximes block muscarinic

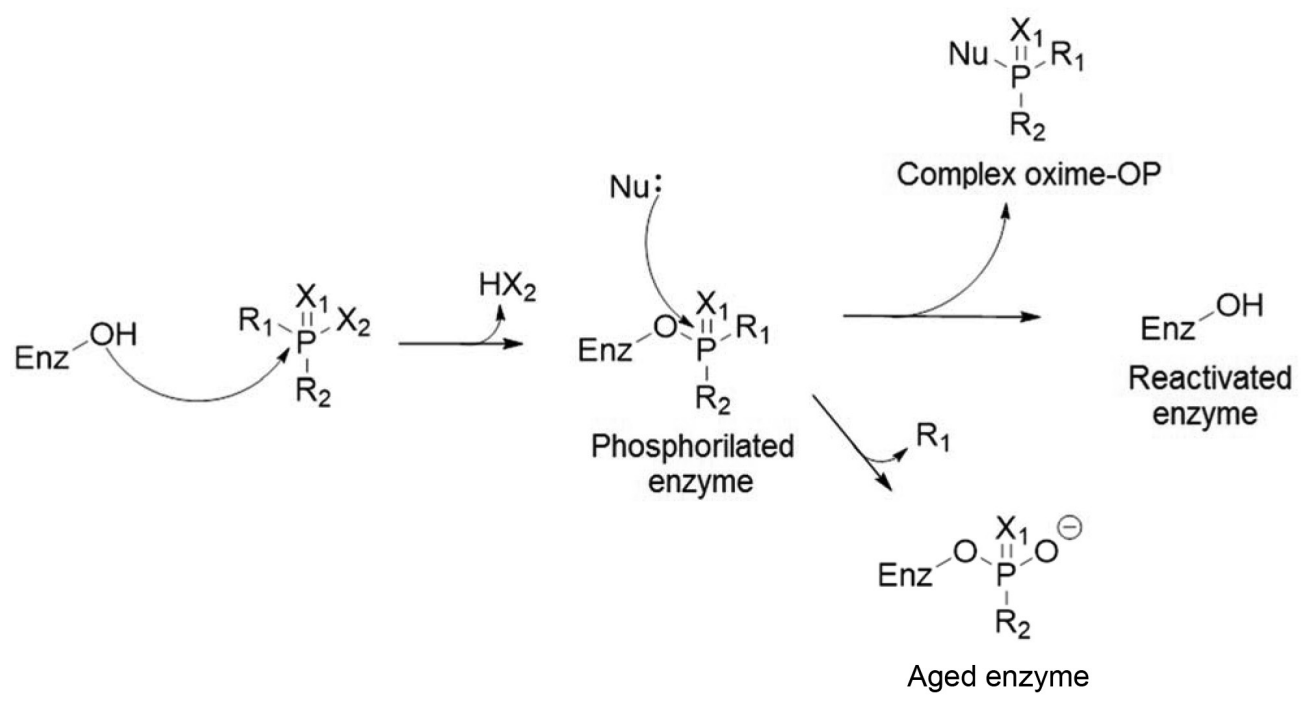

Figure 1. General scheme for the inhibition/aging of esterases and cholinesterases by organophosphorus compounds (OPs) and its reactivation through a nucleophilic agent. $\mathrm{X}_{1}$ can be $O$ or $S$. 
<smiles></smiles>

Pralidoxime<smiles>O/N=C/c1cc[n+](CCC[n+]2ccc(/C=N/O)cc2)cc1</smiles>

TMB-4<smiles>NC(=O)c1cc[n+](COC[n+]2ccccc2/C=N/O)cc1</smiles>

HI-6<smiles>NC(=O)c1cc[n+](COC[n+]2ccc(/C=N/O)cc2/C=N/O)cc1</smiles>

HLö-7<smiles>CCCCn1ccnc1/C=N\O</smiles>

RS-115A<smiles>O=C(/C=N/O)NCCCN1CCCCCC1</smiles>

RS-194C<smiles>NC(=O)c1cc[n+](C/C=C/C[n+]2ccc(/C=N/O)cc2)cc1</smiles>

K203<smiles>O=C(c1ccc[n+](COC[n+]2ccccc2/C=N/O)c1)C1CCCCC1</smiles>

HGG-42

Figure 2. Structures of some oximes.

receptors as $\mathrm{K} 112,{ }^{64} \mathrm{~K} 203$ or $\mathrm{HI}-66^{65}$ and in vitro and in vivo inhibition of nicotinic receptors has been demonstrated by obidoxime, HI-6, K203 and K027 oximes. ${ }^{66}$

\section{Biochemical Aspects of the Biotransforma- tions of Ops}

The biotransformation reactions of OPs (Figure 3) may cause two types of consequences: $(i)$ toxic activation, when the product of the reaction is more soluble in water and more reactive; (ii) detoxication reactions, when the products are less toxic. ${ }^{67}$

The bulk of metabolic activation and detoxification reactions (Figure 3) occur in the liver. Most insecticides are formulated in the form of phosphorothionates because they are more stable than the corresponding oxon forms, such as parathion, chlorpyrifos and diazinon. ${ }^{68}$

Once the thiophosphate (with reduced capability to phosphorylate esterases) has been absorbed by the organism, it is bioactivated through desulfurative oxidation and becomes the corresponding oxon form, with a high capability to phosphorylate esterases (toxic bioactivation). Phosphorothioates and oxonphosphates can be detoxified by several biotransformation reactions. ${ }^{67}$

The $O$-dearylation reaction of phosphorothioates is catalyzed by cytochrome $\mathrm{P} 450$ and yields alkyl phosphates and alkyl phosphorothioates, plus the corresponding alcohol (Figure 3). $O$-Dealkylation is catalyzed by microsomal oxygen and NADPH-dependent enzymes, and it involves hydroxylation at the $\alpha$-carbon atom of an alkyl group. Hydrolysis yields more polar compounds, which are not capable of phosphorylating esterases. The main enzymatic systems involved in the hydrolysis of OPs are phosphotriesterases (PTEs), carboxylesterases (CarbEs) and glutathione-S-transferases. ${ }^{69}$

Sogorb et $a l .{ }^{70}$ classified esterases according to their reactions with $\mathrm{OP}$, in A-esterases, or arylesterases (those that hydrolyze OPs, but are not inhibited by them) and B-esterases (those that are inhibited by them). The A-esterases group is formed mainly by PTEs while B-esterases are CarbEs. PTEs are classified by the International Union of Biochemistry and Molecular Biology (IUBMB) as EC 3.1.8. They are widely spread on the phylogenetic scale and are strongly expressed in the serum and liver of mammals, while levels are barely detectable in birds. ${ }^{71-73}$ The two best understood OP-detoxifying enzymes are the PTE paraoxonase, which hydrolyzes many Ops; ${ }^{74}$ and diisopropylfluorophosphatase (DFPase), which acts on diisopropylfluorophosphate (DFP) and other phosphorofluoridates.

CarbEs are classified by the IUBMB as EC 3.1.1. and can act as scavengers to protect against OPs, facilitated by 


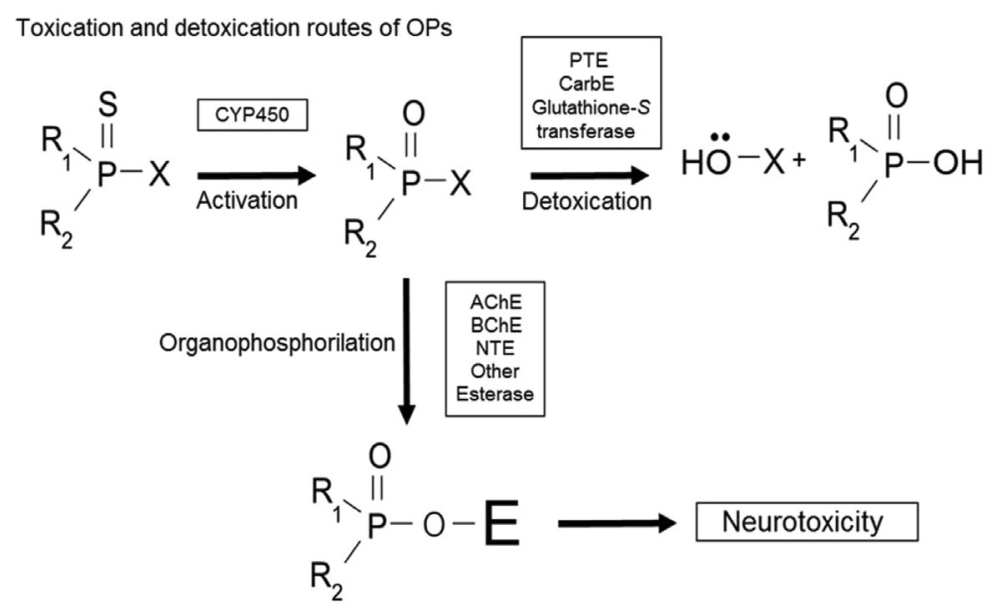

Figure 3. Enzymatic systems involved in organophosphorus compounds (OPs) biotransformation. AChE: Acetylcholinesterase; BChE: butyrilcholinesterase; CarbE: carboxylesterases; NTE: neuropathy target esterase; PTE: phosphotriesterase.

spontaneous reactivation after OP inhibition. Insecticidehydrolyzing esterases are generally better characterized in insects in relation to resistance than in mammals. Resistance to OPs insecticides in several insect species is associated to a high level of expression of CarbEs. These enzymes are expressed in the endoplasmic reticulum of many mammalian tissues. Mammalian CarbEs play key roles in the metabolism of a good number of drugs and xenobiotics. ${ }^{74}$ They all possess an amino acid residue of serine in the active center. This serine is the target of the irreversible phosphorylation by OP that, in some cases, is the cause of toxic effects (as happen with the enzymes AChE or neuropathy target esterase, NTE). In others, however, these inhibitions does not apparently cause toxic effects and such reactions must be considered as detoxication reactions since each molecule of the enzyme is capable of scavenging one molecule of OP from the media. ${ }^{71-73}$ This detoxication system is much less efficient than hydrolysis by PTEs because each CarbE reacts stoichiometrically with OPs and, consequently, this is not a catalytic reaction. Others CarbEs that hydrolyses phenyl valerate have been considered as potential sites of detoxification at low exposure because they are highly sensitive to paraoxon and, also, are able to be spontaneously reactivated when inhibited by this $\mathrm{OP}^{72}$

The role of human serum albumin in OPs detoxication was reported in $1984 .{ }^{75,76}$ More recently, studies have reported the OPs chlorpyrifos-oxon, diazoxon, $O$-hexyl $O$-2,5-dichlorophenyl phosphoramidate (HDCP), paraoxon and soman to be hydrolyzed by albumins from different species. ${ }^{77-79}$ The hydrolysis mechanism is based on the phosphorylation of tyrosine (Tyr) $411 .{ }^{80}$

The final balance between activation routes (oxidative desulfuration) and deactivation routes ( $O$-dearylation, $O$-dealkylation, and specially hydrolysis by PTEs) will become a determinant in the species susceptibility to the toxic effects of OPs.

\section{Toxicokinetics of OPs}

The absorption, distribution, metabolism, excretion (ADME) properties of OPs has been studied in both animal and human species..$^{81}$ OPs can easily cross lipid bilayers, such as alveolar and dermal membranes, because of their lipophilic characteristics. ${ }^{82,83}$ These chemicals can enter the body after exposures from different sources, i.e., ingestion of pesticide residues in food or accidental and intentional ingestion of insecticides; while dermal exposure represents the principal route, particularly during the mixing, loading and application of insecticides, or from skin coming into contact with contaminated surfaces. ${ }^{84}$ Likewise, inhalation is also plausible while spraying pesticides. Based on the bioavailability for a given OP and exposure route, once the compounds have been absorbed, a systemic dose of the parent compound will enter the circulation. OPs are generally well distributed in tissue throughout the body, especially in fatty tissues. These compounds usually do not bio accumulate due to fast biodegradation. ${ }^{73}$ The same property, their lipophilicity, determines slow urine excretion. More stable degradation metabolites are readily excreted in urine and offer the potential utility as biomarkers of exposure. ${ }^{83-86}$ The detection of low levels of metabolites in urine in human populations is a sound evidence for widespread, but low-level, exposures. ${ }^{87}$

\section{Neurotoxicity of OPs}

Extensively data of neurotoxicity of OPs exist from accidental human poisonings, epidemiological studies and animal models ${ }^{88-94}$ OPs can produce several neurotoxic effects depending on the dose, frequency of exposure, type of OP and the host factors that influence susceptibility and sensitivity. In terms of the dose, it is considered low dose 
Table 2. Neurotoxic effects and symptoms observed after exposure to organophosphorus compounds (OPs)

\begin{tabular}{lccc}
\hline Effect & Mainly symptom & Molecular target & OP Implicated \\
Cholinergic crisis & $\begin{array}{c}\text { headache, numbness of extremities, } \\
\text { vomiting, miosis, weakness, muscular } \\
\text { fasciculation, flaccid paralysis, respiratory } \\
\text { difficulty, cardiac arrhythmias }\end{array}$ & AChE & all of them \\
\hline Intermediate syndrome & $\begin{array}{c}\text { moderate proximal limb paralysis, } \\
\text { weakness }\end{array}$ & AChE & most of them \\
\hline OPIDN & $\begin{array}{c}\text { flaccid weakness of the distal limb } \\
\text { muscles, especially in the legs }\end{array}$ & NTE & $\begin{array}{c}\text { ichlorvos, isofenphos, methamidophos, } \\
\text { mipafox, trichlorfon, trichlornat, triaryl } \\
\text { phosphates and phosphamidon/mevinphos } \\
\text { (in humans) }\end{array}$ \\
\hline Potentiation of OPIDN & $\begin{array}{c}\text { enhancement of OPIDN at doses non } \\
\text { neuropathic }\end{array}$ & not identified & $\begin{array}{c}\text { NTE inhibitors (inducers and non- } \\
\text { inducers) }\end{array}$ \\
\hline CNS long term neurotoxicity & $\begin{array}{c}\text { neurobehavioral, neuropsychiatric, } \\
\text { cognitive, sensory-motor }\end{array}$ & not identified & $\begin{array}{c}\text { soman, chlorpyrifos, sarin, not completely } \\
\text { studied }\end{array}$ \\
\hline $\begin{array}{l}\text { Developmental neurotoxicity } \\
\text { neurodevelopmental effects have been } \\
\text { observed in animal outcomes }\end{array}$ & not identified & in vitro observations \\
\hline ACruption of the cannabinoid system & FAAH and MAGL & described with chlorpyrifos \\
\hline studied with chlorpyrifos
\end{tabular}

AChE: Acetylcholinesterase; CNS: central nervous system; FAAH: fatty acid amide hydrolase; MAGL: monoacyl glycerol lipase; NTE: neuropathy target esterase; OPIDN: organophosphorus induced delayed neuropathy.

when no clinical manifestation is observed and/or the serum cholinesterase level, as biomarker, is at more than $50 \%$ of its normal value; a medium dose is achieved when some clinical manifestations are observed like fatigue, headache, dizziness, numbness of extremities, nausea and vomiting, and the serum cholinesterase levels are between 20 and $50 \%$ of the normal value (mid) or between 10 and $20 \%$ of normal value (severe); high levels of exposure trigger severe clinical manifestations like marked miosis and loss of pupillary reflex to light, muscle fasciculation, flaccid paralysis, pulmonary rales, respiratory distress, cyanosis and unconsciousness. This usually happen when the serum cholinesterase level is at less than $10 \%$ of the normal value..$^{95}$

Regarding the dose of OP exposures, it has been observed that similar doses of different OPs cause similar levels of AChE inhibition but may induce different neurotoxic signs. ${ }^{93,96}$ Some of the effects have mechanisms and molecular targets identified while others are less clear. These effects are summarized in Table 2 and the enzymes known as the molecular targets related to them are summarized in Figure 4.

\subsection{Cholinergic crisis, acute toxicity}

The mechanism by which OPs elicit their main toxic effect is the inhibition of AChE as shown in Figure 1, which is the molecular pharmacological target of these compounds. The primary mechanism of action of OPs through AChE inhibition was first described by Dubois and Doull ${ }^{97}$ and Dubois ${ }^{98}$ with parathion and currently

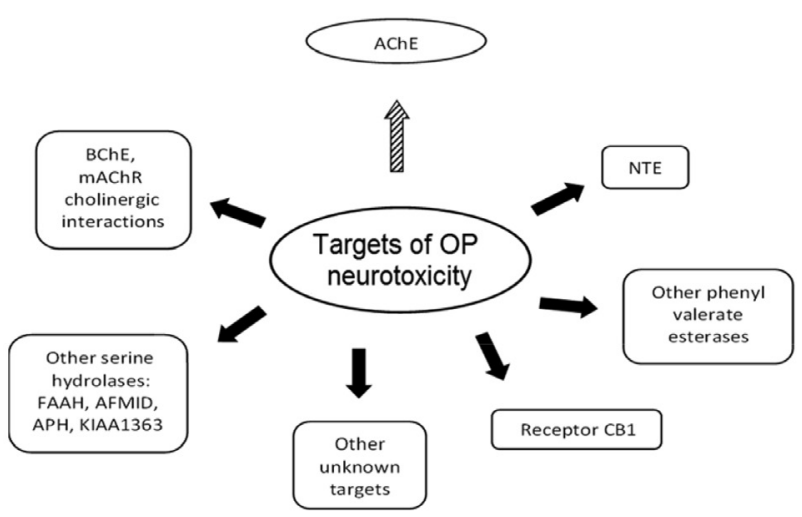

Figure 4. Molecular targets of organophosphorus compounds (OPs). AChE: Acetylcholinesterase; AFMID: arylformamidase; APH: acylpeptide hydrolase; BChE: butyrylcholinesterase; FAAH: fatty acid amide hydrolase; mAChR: muscarinic acetylcholine receptor; NTE: neuropathy target esterase.

the mechanism, from the inhibition of AChE to the development of the symptoms, is well documented. Sufficient AChE inhibition within the synapse prevents the efficient breakdown of acetylcholine (ACh) molecules, leading to its accumulation in the synaptic region and the persistent stimulation of cholinergic receptors on postsynaptic cells. ${ }^{99,100}$ Effects of AChE inhibition (summarized in Table 3) have been well-documented and can be divided into three broad categories: muscarinic effects, nicotinic effects and central nervous system (CNS) effects. Levels of nerve AChE inhibition of approximately over $70 \%$ lead to the accumulation of ACh in synaptic clefts of neuromuscular junctions, which causes neuromuscular block and respiratory failure in severe cases. 
Table 3. Some effects of over stimulation of acetylcholinesterase (AChE) receptors following acute exposure to organophosphorus compounds (OPs)

\begin{tabular}{lc}
\hline Receptor & Clinical sign \\
\hline Muscarinic receptors & $\begin{array}{c}\text { diarrhea, urinary incontinence, } \\
\text { miosis, bradycardia, } \\
\text { bronchoconstriction, } \\
\text { bronchorrhoea, hypotension, } \\
\text { increased gastrointestinal motility, } \\
\text { abdominal cramps, miosis and } \\
\text { hypersalivation }\end{array}$ \\
\hline Nicotinic receptors & $\begin{array}{c}\text { hypertension, tachycardia, } \\
\text { fibrillation, fasciculation, striated } \\
\text { muscle necrosis }\end{array}$ \\
\hline Both central muscarinic and & tremor, loss of movement co- \\
nicotinic receptors & ordination, seizures, central \\
& depression of respiration, coma, \\
& death
\end{tabular}

\subsection{Intermediate syndrome in OPs poisoning}

The intermediate syndrome refers to the health effects observed in patients who survive to acute high-level exposure to the OPs nerve agents. A delayed intermediate syndrome affecting muscles, expressed as weakness, which can occur days following recovery from severe acute effects and reversible over days or weeks, has been reported in some people exposed to OPs. Signs and symptoms include moderate proximal limb paralysis beginning 1-4 days after recovery from the acute effects. ${ }^{101}$ In 1987, Senanayake and Karalliedde ${ }^{102}$ in a landmark paper reported 10 patients who developed facial, proximal limb and respiratory muscle weakness. Several patients, reported before the recognition of intermediate syndrome by Senanayake and Karalliedde ${ }^{102}$ and by Karalliedde ${ }^{103}$ can in retrospect be related to this syndrome. The largest cohort was probably presented by Wadia et al. ${ }^{104}$ for diazinon poisoning. The pathogenesis of intermediate syndrome was unclear and the question arose whether or not intermediate syndrome bore a separate structureactivity relationship. ${ }^{101}$

Some reports describing delayed neuromuscular effect in mice exposed to GB vapor may actually be more related to the intermediate syndrome than to OPIDN. ${ }^{105}$ Nonetheless, the intermediate syndrome's exact mechanism is not understood. The effect is likely to be due to the excessive accumulation of $\mathrm{ACh}$ at the neuromuscular junction that occurs with high-level exposure, leading to prolonged transmitter-receptor interaction. ${ }^{106}$

Manifestation of intermediate syndrome correlates with the severity of acute toxic reaction from exposure to any OP nerve agent. It is related to prolonged inhibition of $\mathrm{AChE}$ activity at the neuromuscular junction and synaptic impairment of neuromuscular transmission and it is not toxicologically related to delayed neuropathy or OPIDN. ${ }^{106}$

\subsection{Organophosphorus induced delayed neuropathy (OPIDN)}

First observation of OPIDN was in 1930 when around 50,000 people were paralyzed in a poisoning epidemic in southern USA due to an adulteration of Jamaica ginger extract, a popular source of alcohol during the prohibition era, with the OPs tri-o-cresyl phosphate (TOCP). Ten thousand Moroccans who ingested TOCP-contaminated cooking oil in 1959, and 600 Indians who consumed contaminated rapeseed oil in 1988 , also became ill. ${ }^{107,108}$ Later, the paralysis of several British workers exposed to mipafox clarified that the ability of TOCP to cause OPIDN was not unique and other OPs also provoked it. This finding spurred the start of still continuing investigations into the mechanism of this syndrome. ${ }^{109}$

OPIDN is a neurodegenerative condition that affects nerves with long fiber tracts in both the CNS and the peripheral nervous system (PNS), causing an axonopathy of long sensorimotor axons in peripheral nerves and spinal cord. ${ }^{110}$ Some OPs, called OPIDN inducers or neuropathic, have been found to induce OPIDN, which is characterized by delayed onset of extended periods of ataxia and upper motor neuron spasticity, arising from single or repeated exposure to OPs. Compounds that have been reported to cause OPIDN in humans are: chlorpyrifos, dichlorvos, isofenphos, methamidophos, mipafox, trichlorfon, trichlornat, triaryl phosphates and phosphamidon/mevinphos. ${ }^{111}$ OPs able to produce OPIDN, called inductors, have to inhibit NTE with a lowest $\mathrm{IC}_{50}$ than AChE. Several OPs have demonstrated to have these properties in vitro with different tissues like fenamiphos ${ }^{112}$ or trichlorfon ${ }^{113}$ in SH-SY5Y human neuroblastoma cells. These cells have demonstrated to be a suitable material to differentiate between neuropathic and non-neuropathic compounds in a simple assay. ${ }^{112}$

OPIDN symptoms usually appear 2 or 3 weeks after a single dose, depending on the kinetic characteristics and the dose of the compound. Initially, the usual complaint is cramping muscle pain in the lower limbs, followed by distal numbness and paresthesia. Progressive weakness then occurs, together with depression of patellar and Achilles reflexes. In severe cases symptoms and signs of neuropathy appear in the arms and forearms and wasting and flaccid weakness of the distal limb muscles, especially in the legs. ${ }^{114}$ Functional recovery occurs with time in less severe cases, with most distal involvement and sparing of spinal cord axons. Otherwise, spastic ataxia may be permanent. 
Young people have reported to recover completely, even from severe lower and upper limb involvement, but not the rest of population. ${ }^{115,116}$ OPIDN has been associated to the interaction with the so called NTE, a protein first discovered as the fraction of phosphorylated protein by neuropathic compounds. ${ }^{117}$ Esterase activity was demonstrated and the inhibition used for monitoring the interaction with OPs. ${ }^{118}$

The mechanism proposed for OPIDN is a multistep hypothesis: (i) OP inducers of OPIDN are by far more potent inhibitors of NTE than AChE; (ii) neuropathic effects are observed only after NTE activity is inhibited by $70-90 \% ; 1^{118}$ (iii) NTE is phosphorylated at the serine residue in the catalytic site; (iv) loss of an alkoxy group (aging) leaves a negatively charged phosphate at the active site; ${ }^{119}$ and $(v)$ a toxic gain of function leads to neurodegeneration. However, the exact mechanism is not completely understood. Although NTE inhibition and aging are necessary conditions to OPIDN, ${ }^{120}$ the precise relationship between NTE and OPIDN has not yet been defined neither the function of NTE has been understood. It has been proposed that the association with NTE inhibition may be an epiphenomenon. ${ }^{121}$ The stereospecificity of chiral OPs in inducing neuropathy has been related with the estereospecificity of the aging reaction.

\subsection{Long term CNS neurotoxicity}

Long term CNS toxicity related to OPs exposure was first reported when, returning from the Gulf War in 1991, thousands of soldiers presented a variety of signs and symptoms of neurological deficits (i.e., attention deficits, memory difficulties and sleep disorders) that were referred to as Gulf War illnesses. Despite intentional exposure to pyridostigmine, exposure to low levels of OPs nerve agents has been associated with these effects. ${ }^{23,121}$

In recent decades, an increasing number of epidemiological studies have suggested that exposure of people to repeated doses of low-medium levels of OPs can produce long term neuropsychological and neurobehavioral effects, that affect the CNS to a greater extent than the PNS, ${ }^{85,88,122-124}$ These effects have also been observed in military personnel, farm workers, ${ }^{82-85}$ sheep dippers exposed to OPs, ${ }^{125}$ and pilots exposed to air contaminated with OPs. ${ }^{91}$ Similar symptoms have also been reported after the acute exposure to GB during the terrorist attack of Tokyo in $1995 .{ }^{27}$

Different symptoms and signs have been observed in several studies and are summarized in Table 4. The phenomenon called as chronic OP-induced neuropsychiatric disorder ${ }^{126}$ can include the following effects: (i) neuropsychiatric effects: depression, fatigue, anxiety, irritability, and emotional state problems; (ii) cognitive effects: attention deficits, reduced visuomotor, perceptual and constructive abilities, verbal learning, speed of processing, memory problems, fatigue and muscle strength, and altered reflexes; (iii) neurobehavioral deficits: lower scores in digit span, digit symbol, and vigilance tasks; and (iv) sensory-motor functions altered.

However, what does not come over clearly are the exact exposure conditions and controversial results have been reported. ${ }^{90,91,127-129}$ Even though intoxication with antiChEs may induce long-term mild changes in neurologic functions, the potential for low-level exposures that lead to chronic neurological changes is even less uncertain and a matter of diverse opinion. At this point, the question arises as to whether or not these effects are caused in doses below those causing acute toxicity or AChE inhibition. Long-term exposure to low or moderate doses of OPs does not cause clinically overt cholinergic toxicity. ${ }^{130}$ However, most studies done in humans based in the biochemical measure of ChE activity over time provide no data on this aspect. Ray and Richards ${ }^{131}$ reviewed the data until 2001, and proposed that any chronic effects of low-level exposures are likely to occur through a mechanism that is independent of AChE inhibition. Jamal et al. ${ }^{132}$ reviewed epidemiological and experimental studies published until 2002 on chronic effects of OPs with or without previous acute cholinergic episodes.

The majority of studies have primarily found associations in the occupational setting and very few studies have searched for chronic neurologic effects beyond the occupational setting. A recent ecological study conducted in Spain in a general population and a large sample size $(\mathrm{n}=17,429)$ indicated a higher prevalence and greater risk for certain neurodegenerative diseases (AD and Parkinson's disease) and suicide attempts in populations living in areas with high use of pesticides, most of which are carbamates and OPs. Ecological bias and other types of confounders preclude etiological interpretations. ${ }^{133}$

Experimental data on low-medium doses of OPs neuro-toxicological outcomes in animals (summarized in Table 5) are abundant, but relatively few have dealt with long-term exposures. In the review by Jamal et al., ${ }^{126}$ five published experimental studies are pointed where chronic OP neurotoxicity was observed with subclinical exposure in primates, rhesus, mice and rats. ${ }^{126,137}$

Most of the reports in the literature deal with repeated exposures to OPs, which are as short as 5 days and are rarely longer than 3 months. ${ }^{134}$ Also, almost all the studies used chlorpyrifos or its metabolite chlorpyrifos oxon as OPs pesticides. Animal experiments studying asymptomatic exposure to OPs have pointed various effects on physiological and behavioral functions. ${ }^{92-95}$ 
Table 4. Long term central nervous system (CNS) neurotoxicity observed in some recent epidemiological studies in people exposed to low-moderate doses of organophosphorus compounds (OPs)

\begin{tabular}{|c|c|c|c|}
\hline Reference & Observation & Country & Biochemical exposure level \\
\hline 133 & $\begin{array}{l}\text { neuropsyquiatric, neurobehavioral effects and } \\
\text { motor alterations symptoms observed in } 59 \text { Indian } \\
\text { workers exposed to different chemicals during the } \\
\text { manufacture of quinalphos }\end{array}$ & India & $\begin{array}{l}\text { mean blood AChE levels in the exposed and in } \\
\text { control group were not different }\end{array}$ \\
\hline 91 & $\begin{array}{c}\text { neuropsyquiatric, neurobehavioral effects in a } \\
\text { cohort with } 27 \text { pilots exposed to engine oil with } \\
\text { OPs }\end{array}$ & UK & not measured \\
\hline 127 & $\begin{array}{c}\text { neuropsyquiatric and neurobehavioral effects in } \\
52 \text { pesticides applicators; a longer duration of } \\
\text { work with pesticides was associated with lower } \\
\text { performance on tests }\end{array}$ & Egypt & $\begin{array}{l}\text { serum AChE was significantly lower in the exposed } \\
\text { group than in the control }\end{array}$ \\
\hline 128 & $\begin{array}{l}\text { farm work was associated with poor performance } \\
\text { on four neurobehavioral tests in } 288 \text { farm workers }\end{array}$ & USA & not measured \\
\hline 89,136 & $\begin{array}{l}\text { neuropsychological dysfunctions and emotional } \\
\text { disturbances observed in } 40 \text { exposed farm workers } \\
\text { measuring cumulative exposure as a number of } \\
\text { years working with pesticides }\end{array}$ & Spain & $\begin{array}{l}\text { no relationship with plasma } \mathrm{BuChE} \text { inhibition as a } \\
\text { measure of recent exposure }\end{array}$ \\
\hline 135 & $\begin{array}{l}\text { functional cognitive effects with increased years of } \\
\text { exposure to OP pesticides in children applicators } \\
\text { of pesticides }\end{array}$ & Egypt & lower AChE activity was also measured \\
\hline
\end{tabular}

AChE: Acetylcholinesterase; BuChE: butyrylcholinesterase.

Table 5. Low-medium doses of central nervous system (CNS) neurotoxicity observed in some animal studies

\begin{tabular}{|c|c|c|}
\hline Reference & Observation & Animal \\
\hline 95 & $\begin{array}{l}\text { hippocampus-dependent learning } \\
\text { and memory effects of repeated } \\
\text { subclinical chlorpyrifos exposure }\end{array}$ & mice \\
\hline 138 & $\begin{array}{l}\text { anxiety and related behavior } \\
\text { neurotoxicity in an acute } \\
\text { exposure to a sub-lethal dose of } \\
\text { soman }\end{array}$ & guinea pig \\
\hline 139 & $\begin{array}{l}\text { potent long-term effect on the } \\
\text { monoaminergic neurotransmitter } \\
\text { systems after low dose of sarin, } \\
\text { with no signs of cholinergic } \\
\text { toxicity or cell death }\end{array}$ & mice \\
\hline
\end{tabular}

\subsection{Disruption of the cannabinoid system}

The cannabinoid system consists of the CB1 and CB2 G protein-coupled cannabinoid receptors in the CNS and the PNS, respectively, and two endocannabinoid ligands, anandamide and 2-arachidonyl glycerol (2-AG), which are biosynthesized and degraded by serine hydrolases fatty acid amide hydrolase (FAAH) and monoacylglycerol lipase (MAGL), respectively. Endocannabinoids are neuromodulators that influence a variety of neurological processes throughout both the PNS and the CNS. ${ }^{140}$ They regulate the release of a variety of neurotransmitters, including $\mathrm{ACh}$, dopamine, glutamate, gamma-aminobutyric acid (GABA) and others in a brain-regional manner. This system is involved in appetite, pain, synaptic plasticity, mood and the psychoactive effects of cannabis. OPs have demonstrated to be able to disrupt this system in various ways. Furthermore, in order to inhibit FAAH and MAGL, OPs block CB1 site(s) ${ }^{141}$ Ex vivo studies with mouse brains suggest that OPs inhibit FAAH much more than CB1 and that these targets generally appear to be less important in poisoning than $\mathrm{AChE}$ and NTE-lysophospholipase (LysoPLA). ${ }^{142,143}$ However, some OPs are MAGL and FAAH strong inhibitors that act at $0.1-1 \mathrm{nmol} \mathrm{L}^{-1}$ in vitro and at $1-10 \mathrm{mg} \mathrm{kg}^{-1}$ in vivo. ${ }^{144}$

Indeed, a number of studies have also reported the inhibition of hippocampal ACh release by endocannabinoids. ${ }^{145}$ A proposed mechanism is: (i) OP inhibit AChE and (ii) ACh accumulation in a brain-regional manner activates $\mathrm{CB}$ signaling, which could modulate the degree of ACh.

Chemicals that can enhance CB signaling have been seen to reduce the functional and neurobehavioral signs of toxicity in rats following $\mathrm{OP}$ anti-ChE exposure. ${ }^{146,147}$ Similar cholinergic toxicity and AChE inhibition have been observed after the acute treatment of chlorpyriphos in mice CB1(-/-) and the wild type. However, chlorpyrifos significantly reduces hippocampal $\mathrm{ACh}$ release ex vivo in both, but significantly more so in CB1(-/-). ${ }^{148}$ However, current OPs insecticides normally used do not appear to pose any cannabinoid-related toxicity problems and further 
research is ongoing in other directions. Selective and reversible carbamate FAAH and MAGL inhibitors have been designed for pain relief purposes and this selective blockade of 2-arachidonoylglycerol hydrolysis produces cannabinoid behavioral effects. ${ }^{149}$

\section{Interaction with Other Esterases and Future Perspectives}

There is a lack of a good relationship between some of the long term effects of OPs and the magnitude and regional selectivity of AChE inhibition. ${ }^{150}$ Also, between the inhibition of NTE and the production of the effects of OPIDN. ${ }^{151}$ OPs inhibit not only AChE and NTE but also many other esterases, most of them in the family of serine hydrolases. Any serine hydrolase can be sensitive to OPs due to the nucleophilic nature of the serine residue present in these hydrolytic enzymes. ${ }^{96,152}$ The possibility of the relationship between the inhibition of esterases and the toxicological effects of OPs have been studied in the last years by several groups. ${ }^{153-161}$ This interactions have been experimentally observed and quantified by enzymatic activity assays on specific substrates, ${ }^{160,161}$ by activitybased protein profiling studies, ${ }^{162,163}$ by exhaustive kinetic characterization with OPs models and phenyl valerate as a non-specific substrate for esterases ${ }^{164-169}$ and through further separation and fractionation protein studies in chicken brain. ${ }^{165} \mathrm{~A}$ recent study, using high performance liquid chromatography tandem mass spectrometry (LC-MS/MS) proteomic identification, pointed butyril cholinesterase (BuChE) as an esterase highly sensitive to paraoxon and mipafox that hydrolyzes phenyl valerate in chicken brain. ${ }^{167}$ However, most of these esterases are not molecularly identified and other experimental interactions are not completely related with the biological effects of OPs yet. Linking these in vitro results to the observed toxic effects of OPs is a future research direction and the complete molecular identification of the whole pool of esterases interacting with OPs will be useful to understand their long term and low, medium level effects. ${ }^{170}$ The safety of the continued use of OPs in agriculture and the treatment of poisoning by OPs in accidents or terrorist attacks depend on the knowledge of these toxicological targets and pathways.

\section{Acknowledgments}

The authors wish to thank the Brazilian financial agencies Conselho Nacional de Desenvolvimento Científico e Tecnológico (CNPq, grant 474757/2012-9), Fundação de Amparo ao Ensino e Pesquisa do Estado do Rio de Janeiro
(FAPERJ, grant E-26/102.993/2012), and Coordenação de Aperfeiçoamento de Pessoal de Nível Superior (BJTACAPES, grant 88887.065877/2014-00) for financial support, and the Instituto de Engenharia Militar (IME) for providing the physical infrastructure and working space. This work was also supported by Excellence project FIM.

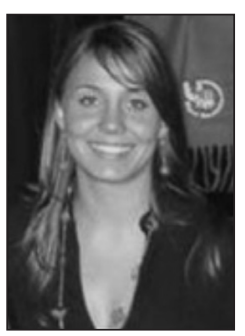

Iris Mangas obtained her BSc in Pharmacy at Universidad Miguel Hernández (UMH, Spain) in 2008, her MsC on Enviromental Toxicology at Universidad de Valencia (Spain) in 2010 and her MsC on Public Health at UMH (Spain). She obtained her PhD in Toxicology in 2014 at UMH (Spain). She worked as visitor researcher at University of California (San Diego, United States) in 2012. Currently, she is a young talent researcher, level A-CAPES at Instituto Militar de Engenheria, Rio de Janeiro (Brazil) since September 2014. Member of the Society of Toxicology, Hispanic Association of Toxicology and Sociedade Brasilera de Toxicologia, and Member of the Brazilian Chemical Society. Her research is in enzymes interacting with organophosphorus pesticides and chemical weapons thought kinetic characterization, mass spectrometry, chromatography and molecular modeling approaches, computer-aided drug design of new inhibitors and reactivators of cholinesterases as potential drugs for Alzheimer's disease. Publications: more than 15 papers peer-reviewed journals (9 full articles), and 3 books chapters. Participation in several invited seminars and international congresses.

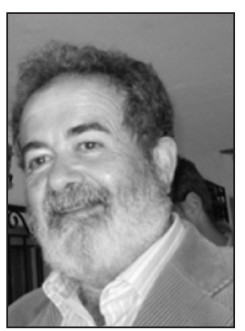

Eugenio Vilanova obtained his $B S c$ in Chemistry at Universidad de Valencia in 1972, and obtained his PhD in Chemistry in 1980 at University of Alicante. He was professor of Biochemistry (since 1985) and currently he is full professor of Toxicology (since 1998), director of the Institute of Bioengineering, (since 2005) at Universidad Miguel Hernández (Elche, Spain). President of the Spanish Association Toxicology (1995-2001); honorary member of Eurotox; president of the International Congress Toxicology 2010, Eurotox 96 research in enzymes interacting with organophosphorus and other environmental neurotoxicants; biodegradation, neurotoxicity, embryotoxicity, gene biomarkers, and cell differentiation; monitoring and biomonitoring of solvents, metals, pesticides and plasticizers. Publications: more than 200 papers peer- 
reviewed journals (95 full articles), books, chapters, adviser of $18 \mathrm{PhD}$. Participation in 62 international congresses. Editorial board: Toxicology Letters, Archives of Toxicology, and reviewers of other. Advising for safety (nanomaterials, biocides, pesticides and others) to industry, government and European agencies (biocides, chemical agency, and pesticides).

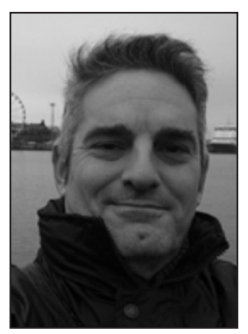

Jorge Estévez obtained his BSc in Biochemistry at University of Alicante in 1997. He obtained his PhD in Biochemistry in 2003 at Universidad Miguel Hernández (UMH) of Elche. He worked as researcher visitor at Department of Genome Sciences of The University of Washington in 2015. Currently, he is Assistant Professor of Toxicology, (since 2009) at UMH, Elche (Spain). Member of the Spanish competent authority team in charge of biocides risk assessment assigned to Spain by the European Commission; member of the Board of Spanish Network for the Development of Alternative Methods to the Animal Experimentation (REMA). Research in enzymes interacting with organophosphorus and other environmental neurotoxicants, biodegradation and neurotoxicity. Publications: more than 30 papers peer-reviewed journals (18 full articles), 3 books chapters, adviser of 2 PhD. Participation in 37 international congresses. Member of organizing committee: International Congress of Toxicology (IUTOX 2010), $12^{\text {th }}$ Ecopa (European Consensus Platform For Alternatives) Annual Workshop, $12^{\text {th }}$ International Meeting on Cholinesterases-Sixth International Conference on Paraoxonases.

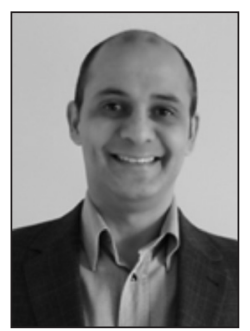

Tanos Celmar Costa França obtained his BSc in Chemical Engineering at the Federal Rural University of Rio de Janeiro (Brazil) in 1993, his MSc in Organic Chemistry at the Federal University of Rio de Janeiro (Brazil) in 1998, and his PhD in Chemistry at the Military Institute of Engineering (Rio de Janeiro, Brazil) in 2004. He worked as visitor scholar at the Skaggs School of Pharmacy and Pharmaceutical Sciences of the University of California (San Diego, United States) in 2012/2013. Currently, is professor of Chemistry and Chemical Defense at the Military Institute of Engineering, Rio de Janeiro (Brazil) since February of 2004, invited professor at the Faculty of Informatics and Management of the University of Hradec Kralove in Czech Republic since November of 2014, and visitor researcher at the Concordia University in Montreal, Canada, since September of 2015. He is also member of the Brazilian Chemical Society since 1993, and the American Chemical Society since 2011 and develops research mainly on the design of new antidotes against chemical warfare agents and drugs against biological warfare agents using molecular modeling tools. Publications: more than 70 papers in peer-reviewed journals, 87 meeting communications, 1 edited book, 11 book chapters. Member of editorial board of the journals Military Medical Science Letters and Revista Virtual de Química.

\section{References}

1. Gupta, R. C. In Toxicology of Organophosphate and Carbamate Compounds; Gupta, R. C., ed.; Academic Press: San Diego, 2006, ch. 2.

2. Brown, A. W. A.; W. H. O. Monogr. Ser. 1958, 38, 11.

3. Brown, A. W. A.; Advances in Pest Control Research, Volume 1, $1^{\text {st }}$ ed.; Interscience Publishers: New York, 1958.

4. Metcalf, R. L.; Organic Insecticides, Their Chemistry and Mode of Action, Volume 1, $1^{\text {st }}$ ed.; Interscience Publishers: New York, 1955.

5. Satoh, T.; Hosokawa, M.; Neurotoxicology 2000, 21, 223.

6. Lowit, A. B. In Toxicology of Organophosphate and Carbamate Compounds; Gupta, R. C., ed.; Academic Press: San Diego, 2006, ch. 42.

7. Casida, J. E.; Quistad, G. B.; Chem. Res. Toxicol. 2004, 8, 983.

8. Casida, J. E.; Quistad, G. B.; Chem.-Biol. Interact. 2005, 157, 277.

9. Casida, J. E.; Durkin, K. A.; Annu. Rev. Entomol. 2013, 58, 99.

10. United States Environmental Protection Agency (US EPA); Pesticides Industry Sales and Usage 2006 and 2007 Market Estimates. Biological and Economic Analysis Division Office of Pesticide Programs; U.S. Agency Office of Chemical Safety and Pollution Prevention: Washington D.C., February 2011.

11. Casida, J. E.; Durkin, K. A.; Chem.-Biol. Interact. 2013, 203, 221.

12. Costa, L. G.; Clin. Chim. Acta 2006, 366, 1.

13. Neves, P. D.; Bellini, M.; Ciên. Saude Coletiva 2013, $18,3147$.

14. Ragoucy-Sengler, C.; Tracqui, A.; Chavonnet, A.; Daijardin, J. B.; Simonetti, M.; Kintz, P.; Pileire, B.; Hum. Exp. Toxicol. 2000, 19, 657.

15. Corrêa, C. L.; Zambrone, F. A. D.; Cazarin, K. C. C.; Rev. Bras. Toxicol. 2004, 17, 71.

16. Leme, T. S.; Papini, S.; Vieira, E.; Luiz, C. L.; Cad. Saúde Pública 2014, 30, 3.

17. Ferreira, H. P.; Taguchi, C. K.; Tomita, S.; Fátima, M. M.; Rev. Bras. Otorrinolaringol. 2008, 74, 6.

18. http://sinitox.icict.fiocruz.br/dados-de-agentes-toxicos accessed in March 2016. 
19. Barr, D. B.; Bravo, R.; Weerasekera, G.; Caltabiano, L. M.; Whitehead, R. D.; Olsson, A. O.; Caudill, S. P.; Schober, S. E.; Pirkle, J. L.; Sampson, E. J; Jackson, R. J.; Needham, L. L.; Environ. Health Perspect. 2004, 112, 186.

20. United States Department of Agriculture (USDA); Pesticide Data Program Annual Summary; Monitoring Programs Office: Washington D.C., 2005.

21. Delfino, R. T.; Ribeiro, T. S.; Figueroa-Villar, J. D.; J. Braz. Chem. Soc. 2009, 20, 407.

22. Marrs, T. C.; Maynard, R. L.; Sidell, F. R.; Chemical Warfare Agents: Toxicology and Treatment; John Wiley and Sons: Oxford, 1996.

23. Research Advisory Committee (RAC) on Gulf War Veterans' Illnesses; Gulf War Illness and the Health of Gulf War Veterans. Scientific Findings and Recommendations; U.S. Government Printing Office: Washington D.C., November 2008.

24. Ministério do Exército; Manual de Campanha-Operações Químicas, Biológicas e Nucleares-Defesa Contra Ataques Químicos, Biológicos e Nucleares; Estado-Maior do Exército: Brasília, DF, Brasil, 1987.

25. Marrs, T. C.; Maynard, R. L.; Sidell, F. R.; Chemical Warfare Agents: Toxicology and Treatment, $2^{\text {nd }}$ ed.; John Wiley \& Sons: Oxford, 2007.

26. Joy, R. J. T. In Medical Aspects of Chemical and Biological Warfare-Textbook of Military Medicine; Sidell, F. R.; Takafuji, E. T.; Franz, D. R., eds.; Office of the Surgeon General at TMM Publications, Water Reed Army Medical Center: Washington D.C., 1997, p. 87.

27. Takafuji, E. T.; Kok, A. B. In Medical Aspects of Chemical and Biological Warfare-Textbook of Military Medicine; Sidell, F. R.; Takafuji, E. T.; Franz, D. R., eds.; Office of the Surgeon General, US Army: Washington D.C., 1997.

28. Nagao, M.; Takatori, T.; Matsuda, Y.; Nakajima, M.; Iwase, H.; Iwadate, K.; Toxicol. Appl. Pharmacol. 1997, 144, 198.

29. Yanagisawa, N.; Morita, H.; Nakajima, T.; J. Neurol. Sci. 2006, 249, 76.

30. Suzuki, T.; Morita, H.; Ono, K.; Maekawa, K.; Nagai, R.; Yazaki, Y.; Lancet 1995, 345, 980

31. Masuda, N.; Takatsu, M.; Morinari, H.; Ozawa, T.; Lancet 1995 $345,1446$.

32. Dolgin, E.; Nat. Med. (N. Y., NY, U. S.) 2013, 10, 1194.

33. Rosman, Y.; Eisenkraft, A.; Milk, N.; Shiyovich, A.; Ophir, N.; Shrot, S.; Kreiss, Y.; Kassirer, M.; Ann. Intern. Med. 2014, 160, 644.

34. Worek, F.; Thiermann, H.; Wille, T.; Toxicol. Lett. 2015, S0378, 30016.

35. Karczmar, A.; Neurochem. Int. 1998, 32, 401.

36. Taylor, P. In Goodman \& Gilman's the Pharmacological Basis of Therapeutics; Hardman, J. G., Limbird, L. E., eds.; McGrawHill: New York, 2011, ch. 10.

37. Costa, L. G.; Giordano, G.; Guizzetti, M.; Vitalone, A.; Front. Biosci., Landmark Ed. 2008, 13, 1240.
38. Metcalf, R. L.; March, R. B.; J. Econ. Entomol. 1959, 42, 721

39. Toy, A. D. F.; J. Am. Chem. Soc. 1950, 72, 2065.

40. Metcalf, R. L.; Bull. Entomol. Soc. Am. 1959, 5, 3.

41. Farbenfabriken Bayer Akt.-Ges.; British pat. 806,148 1958.

42. Schrader, G.; Lorenz, W.; Colin, R.; Schlov, H.; Belgian pat. 576,8111959

43. Aldridge, W. N.; Bull. W. H. O. 1971, 44, 23.

44. Czerwinski, S. E.; Skvorak, J. P.; Maxwell, D. M.; Lenz, D. E.; Baskin, S. I.; J. Biochem. Mol. Toxicol. 2006, 20, 241.

45. Bowman, B. T.; Sans, W. W.; J. Environ. Sci. Health, Part B 1982, B18, 667.

46. Sogorb, M. A.; Vilanova, E. In Anticholinesterases Pesticides. Metabolism, Neurotoxicity, and Epidemiology; Satoh, T.; Gupta, R. C., eds.; Academic Press: San Diego, 2006, ch. 10.

47. Sogorb, M. A.; Vilanova, E.; Toxicol. Lett. 2002, 128, 215.

48. Gonçalves, A. S.; França, T. C. C.; Figueroa-Villar, J. D.; Pascutti, P. G.; J. Braz. Chem. Soc. 2011, 22, 155.

49. Gonçalves; A. S.; França, T. C.; Caetano, M. S.; Ramalho, T. C.; J. Biomol. Struct. Dyn. 2014, 32, 301.

50. Barril, J.; Estévez, J.; Escudero, M. A.; Céspedes, M. V.; Níguez, N.; Sogorb, M. A.; Monroy, A.; Vilanova, E.; Chem.-Biol. Interact. 1999, 119, 541.

51. Mangas, I.; Taylor, P.; Vilanova, E.; Estévez, J.; França, T. C. C.; Komives, E.; Radić, Z.; Arch. Toxicol. 2016, 90, 603.

52. Nachon, F.; Carletti, E.; Wandhammer, M.; Nicolet, Y.; Schopfer, L. M.; Masson, P.; Lockridge, O.; Biochem. J. 2011, 434, 73.

53. Jennings, L. L.; Malecki, M.; Komives, E. A.; Taylor, P.; Biochemistry 2003, 42, 11083.

54. Segall, Y.; Waysbort, D.; Barak, D.; Ariel, N.; Doctor, B. P.; Grunwald, J.; Ashani, Y.; Biochemistry 1993, 32, 13441.

55. Giacoppo, J. O.; França, T. C. C.; Kuča, K.; da Cunha, E. F.; Abagyan, R.; Mancini, D. T.; Ramalho, T. C.; J. Biomol. Struct. Dyn. 2015, 33, 2048.

56. da Silva, G. A.; França, T. C. C.; Caetano, M. S.; Ramalho, T. C.; J. Biomol. Struct. Dyn. 2014, 32, 301.

57. Bismuth, C.; Inns, R. H.; Marrs, T. C.; In Clinical and Experimental Toxicology of Organophosphates and Carbamates; Ballantyne, B.; Marrs, T. C., eds.; Butterworth-Heinemann: Oxford, 1992, ch. 52

58. Worek, F.; von der Wellen, J.; Musilek, K.; Kuca, K.; Thiermann, H.; Arch. Toxicol. 2012, 86, 1379.

59. Ekström, F.; Hörnberg, A.; Artursson, E.; Hammarström, L. G.; Schneider, G.; Pang, Y. P.; PLoS One 2009, 4, e5957.

60. Sanson, B.; Nachon, F.; Colletier, J. P.; Froment, M. T.; Toker, L.; Greenblatt, J. L.; J. Med. Chem. 2009, 52, 7593.

61. Kropp, T. J.; Richardson, R. J.; Chem. Res. Toxicol. 2007, 20, 504.

62. Musilek, K.; Dolezal, M.; Gunn-Moore, F.; Kuca, K.; Med. Res. Rev. 2011, 31, 548. 
63. Almeida, J. S. F. D.; Guizado, T. R. C.; Guimarães, A. P.; Ramalho, T. C.; Goncalves, A. S.; Koning, M. C.; Franca, T. C. C.; J. Biomol. Struct. Dyn. 2015, 27, 1.

64. Soukup, O.; Kristofikova, Z.; Proska, J.; Tobin, G.; Patocka, J.; Marek, J.; Jun, D.; Fusek, J.; Ripova, D.; Kuca, K.; Biomed. Pharmacother. 2010, 64, 541.

65. Kuca, K.; Cabal, J.; Jung, Y. S.; Musilek, K.; Soukup, O.; Jun, D.; Pohanka, M.; Musilova, L.; Karasová, J.; Novotný, L.; Hrabinova, M.; Basic Clin. Pharmacol. Toxicol. 2009, 105, 207.

66. Soukup, O.; Krůšek, J.; Kaniaková, M.; Kumar, U. K.; Oz, M.; Jun, D.; Fusek, J.; Kuča, K.; Tobin, G.; Physiol. Res. (Prague, Czech Repub.) 2011, 60, 679.

67. Sultatos, L. G.; J. Toxicol. Environ. Health 1994, 3, 271.

68. Jokanović, M.; Toxicology 2001, 166, 139.

69. Neuberger, A.; Tatum, E. L. In Enzyme Inhibitors as Substrates: Interactions of Esterases with Esters of Organophosphorus and Carbamic Acids; Aldridge, W. N.; Reiner, E., eds.; NorthHolland Publishing Company: Amsterdam, 1972.

70. Sogorb, M. A.; Vilanova, E.; Quintanar, J. L.; Viniegra, S.; Int. J. Biochem. Cell Biol. 1996, 9, 983.

71. Vilanova, E.; Sogorb, M. A.; Crit. Rev. Toxicol. 1999, 1, 21.

72. Sogorb, M. A.; Vilanova, E.; Carrera, V.; Toxicol. Lett. 2004, $151,219$.

73. Costa, L. G.; McDonald, B. E.; Murphy, S. D.; Omenn, G. S.; Richter, R. J.; Motulsky, A. G.; Furlong, C. E.; Toxicol. Appl. Pharmacol. 1990, 103, 66.

74. Satoh, T.; Hosokawa, M.; Annu. Rev. Pharmacol. Toxicol. 1998, $38,257$.

75. Ortigoza-Ferado, J.; Richter, R. J.; Hornung, S. K.; Motulsky, A. G.; Furlong, C. E.; Am. J. Hum. Genet. 1984, 2, 295.

76. Furlong, C. E.; Richter, R. J.; Seidel, S. L.; Motulsky, A. G.; Am. J. Hum. Genet. 1988, 3, 230.

77. Sogorb, M. A.; Monroy, A.; Vilanova, E.; Chem. Res. Toxicol. 1998, 12, 1441.

78. Sogorb, M. A.; García-Argüelles, S.; Carrera, V.; Vilanova, E.; Chem. Res. Toxicol. 2008, 8, 1524.

79. Sogorb, M. A.; Sánchez, I.; López-Rivadulla, M.; Céspedes, V.; Vilanova, E.; Drug Metab. Dispos. 1999, 1, 53.

80. Li, W. F.; Furlong, C. E.; Costa, L. G.; Toxicol. Lett. 1995, 76, 219.

81. Poet, T. S.; Kousba, A. A.; Dennison, S. L.; Timchalk, C.; Toxicol. Sci. 2003, 72, 193.

82. World Health Organization (WHO); Properties and Analytical Methods. In Organophosphorus Insecticides: A General Introduction, World Health Organization, Geneva, ch. 3.

83. World Health Organization (WHO); Organophosphorus Insecticides: a General Introduction (Environmental Health Criteria 63), Report on The International Programme on Chemical Safety (IPCS): Geneva, 1986, ch. 6.

84. Knaak, J. B.; Al-Bayati, M. A.; Raabe, O. G. In Health Risk Assessment: Dermal and Inhalation Exposure and Absorption of Toxicants (Dermatology: Clinical \& Basic Science); Wang, R. G. M.; Knaak, J. B.; Maibach, H. I., eds.; CRC Press: Boca Raton, 1993.

85. Colosio, C.; Fustinoni, S.; Birindelli, S.; Bonomi, I.; de Paschale, G.; Mammone, T.; Tiramani, M.; Vercelli, F.; Visentin, S.; Maroni, M.; Toxicol. Lett. 2002, 134, 133.

86. Iverson, F.; Grant, D. L.; Lacroix, J.; Bull. Environ. Contam. Toxicol. 1975, 5, 611.

87. Aprea, C.; Betta, A.; Catenacci, G.; Lotti, A.; Magnaghi, S.; Barisano, A.; Passini, V.; Pavan, I.; Sciarra, G.; Vitalone, V.; Minoia. C.; J. AOAC Int. 1999, 82, 305.

88. Hausherr, V.; van Thriel, C.; Krug, A.; Leist, M.; Schöbel, N.; Toxicol. Sci. 2014, 142, 274.

89. Roldán-Tapia, L.; Nieto-Escamez, F. A.; del Aguila, E. M.; Laynez, F.; Parron, T.; Sanchez-Santed, F.; Neurotoxicol. Teratol. 2006, 28, 694.

90. Bazylewicz-Walczak, B.; Majczakowa, W.; Szymczak, M.; Neurotoxicology 1999, 5, 819.

91. Mackenzie-Ross, S. J.; J. Nutr. Environ. Med. 2008, 17, 111.

92. Moser, V. C.; Hum. Exp. Toxicol. 2007, 4, 321.

93. Scremin, O. U.; Shih, T. M.; Huynh, L.; Roch, M.; Booth, R.; Jenden, D. J.; J. Pharmacol. Exp. Ther. 2003, 304, 1111.

94. Mach, M.; Grubbs, R. D.; Price, W. A.; Nagaoka, M.; Dubovický, M.; Lucot, J. B.; J. Appl. Toxicol. 2008, 28, 132.

95. Terry, A. V.; Stone, J. D.; Buccafusco, J. J.; Sickles, D. W.; Sood, A.; Prendergast, M. A.; J. Pharmacol. Exp. Ther. 2003, 305, 375.

96. Pope, C. N.; J. Toxicol. Environ. Health, Part B 1999, $2,161$.

97. Dubois, K. P.; Doull, J.; J. Pharmacol. Exp. Ther. 1949, 95, 79.

98. Dubois, K. P.; J. Am. Pharm. Assoc. (1912-1977) 1948, $37,307$.

99. Ecobichon, D. J. In Anticholinesterase Pesticides. Metabolism, Neurotoxicity and Epidemiology; Satoh, T.; Gupta, R. C., eds.; John Wiley \& Sons: Cambridge, 2010, p. xiii.

100. Ecobichon, D. J. In Casarett \& Doull's Toxicology. The Basic Science of Poisons; Klaasen, C. D., ed.; McGraw-Hill: New York, 1996, p. 643.

101. Karalliedde, L.; Baker, D.; Marrs, T. C.; Toxicol. Rev. 2006, 25 , 1.

102. Senanayake, N.; Karalliedde, L.; N. Engl. J. Med. 1987, 316, 761.

103. Karalliedde, L.; Anaesthesia 1999, 54, 1073.

104. Wadia, R. S.; Ichaporia, R. N.; Karnik, V. M.; Relwani, G. S.; Grant, K. B.; J. Indian Med. Assoc. 1972, 59, 234.

105. Brown, M. A.; Brix, K. A.; J. Appl. Toxicol. 1998, 18, 393.

106. Karalliedde, L.; Henry, J. A.; Hum. Exp. Toxicol. 1993, 4, 289. 107. Smith, H. V.; Spalding, J. M.; Lancet 1959, 2(7110), 1019.

108. Ehrich, M.; Jortner, B. S. In Handbook of Pesticide Toxicology, Volume 2; Krieger, R. I., ed.; Academic Press: San Diego, 2006, ch. 49.

109. Davison, A. N.; Br. J. Pharmacol. 1953, 8, 212. 
110. Davis, C. S.; Richardson, R. J. In Experimental and Clinical Neurotoxicology; Spencer, P. S.; Schaumburg H. H., eds.; Williams \& Wilkins, 1980, p. 527.

111. Moretto, A.; Lotti M. In Toxicology of Organophosphate and Carbamate Compounds; Gupta, R. C., ed.; Academic Press: San Diego, 2006, ch. 25.

112. Emerick, G. L.; Fernandes, L. S.; de Paula, E. S.; Barbosa, F. Jr.; dos Santos, N. A.; dos Santos, A. C.; Toxicol. in vitro 2015, 29, 1079.

113. Fernandes, L. S.; Emerick, G. L.; dos Santos, N. A. G.; de Paula, E. S.; Barbosa Jr., F.; dos Santos, A. C. Toxicol. in vitro, 2015, 29, 522.

114. Moretto, A.; Lotti, M.; J. Neurol. Neurosurg. Psychiatry 1998, 64, 463.

115. Senanayake, N. J.; J. Neurol. Neurosurg. Psychiatry 1981, 44, 775.

116. Goldstein, D. A.; McGuigan, M. A.; Ripley, B.D.; Hum. Toxicol. 1988, 2, 179.

117. Johnson, M. K.; Lauwerys, R.; Nature (London, U. K.) $\mathbf{1 9 6 9 ,}$ $222,1066$.

118. Johnson, M. K.; Rev. Biochem. Toxicol. 1982, 4, 141.

119. Johnson, M. K.; J. Neurochem. 1974, 4, 785.

120. Winrow, C. J.; Hemming, M. L.; Allen, D. M.; Quistad, G. B.; Casida, J. E.; Barlow, C.; Nat. Genet. 2003, 33, 477.

121. McCauley, L. A. In Toxicology of Organophosphate and Carbamate Compounds; Gupta, R. C., ed.; Academic Press: San Diego, 2006, ch. 6.

122. Committee on Toxicity (COT); Organophosphates. A Report of the Committee on Toxicology of Chemicals in Food, Consumer Products and the Environment, COT Report on Organophosphates; U.K. Department of Health: London, 1999.

123. Colosio, C.; Tiramani, M.; Brambilla, G.; Colombi, A.; Moretto, A.; Neurotoxicology 2009, 6, 1155.

124. Parrón, T.; Hernández, A. F.; Villanueva, E.; Forensic Sci. Int. 1996, 79, 53.

125. Dunn, G.; Report on an Analytical Study of OP Sheep Dips; U.K. Veterinary Medicines Directorate: London, 2002.

126. Jamal, G. A.; Hansen, S.; Pilkington, A.; Buchanan, D.; Gillham, R. A.; Abdel-Azis, M.; Julu, P. O. O.; Al-Rawas, S. F.; Hurley, F.; Ballantyne, J. P.; Occup. Environ. Med. 2002, 59, 434.

127. Farahat, T. M.; Abdelrasoul, G. M.; Amr, M. M.; Shebl, M. M.; Farahat, F. M.; Anger, W. K.; Occup. Environ. Med. 2003, 60, 279.

128. Kamel, F.; Rowland, A. S.; Park, L. P.; Anger, W. K.; Baird, D. D.; Gladen, B. C.; Environ. Health Perspect. 2003, 111, 1765.

129. Rohlman, D. S.; Anger, W. K.; Lein, P. J.; Neurotoxicology 2011, 32, 268.

130. Romano Jr., J. A.; McDonough, J. H.; Sheridan, R.; Sidell, F. R. In Chemical Warfare Agents: Toxicity at Low Levels; Somani, S. M.; Romano Jr., J. A., eds.; CRC Press: New York, 2001, ch. 1 .
131. Ray, D. E.; Richards, P. G.; Toxicol. Lett. 2001, 120, 343.

132. Jamal, G. A.; Hansen, S.; Julu, P. O.; Toxicology 2002, 181, 23.

133. Roldán-Tapia, L.; Parrón, T.; Sánchez-Santed, F.; Neurotoxicol. Teratol. 2005, 2, 259.

134. Srivastava, A. K.; Gupta, B. N.; Bihari, V.; Mathur, N.; Srivastava, L. P.; Pangtey, B. S.; Bharti, R. S.; Kumar, P.; Food Chem. Toxicol. 2000, 38, 65.

135. Abdel-Rasoul, G. M.; Abou-Salem, M. E.; Mechael, A. A.; Hendy, O. M.; Rohlman, D. S.; Ismail, A. A.; Neurotoxicology 2008, 29, 833 .

136. Parrón, T.; Requena, M.; Hernández, A. F.; Alarcón, R.; Toxicol. Appl. Pharmacol. 2011, 256, 379.

137. Meerdink, G. L.; Vet. Clin. North Am.: Food Anim. Pract. 1989, 5,375 .

138. Mamczarz, J.; Pereira, E. F.; Aracava, Y.; Albuquerque, A. M.; Neurotoxicology 2010, 1, 77.

139. Oswal, D. P.; Garrett, T. L.; Morris, M.; Lucot, J. B.; Neurochem. Res. 2013, 38, 108.

140. Pope, C. N.; Mechoulam, R.; Parsons, L.; Neurotoxicology 2010, 31, 562.

141. Deutsch, D. G.; Omeir, R.; Arreaza, G.; Salehani, D.; Prestwich, G. D.; Huang, Z.; Howlett, A.; Biochem. Pharmacol. (Amsterdam, Neth.) 1997, 53, 255.

142. Quistad, G. B.; Sparks, S. E.; Casida, J. E.; Toxicol. Appl. Pharmacol. 2001, 173, 48.

143. Segall, Y.; Quistad, G. B.; Nomura, D. K.; Casida, J. E.; Bioorg. Med. Chem. Lett. 2003, 13, 3301.

144. Nomura, D. K.; Casida, J. E.; J. Agric. Food Chem. 2011, 597, 2808.

145. Degroot, A.; Nomikos, G. G.; Curr. Opin. Pharmacol. 2007, 1, 62.

146. Nallapaneni, A.; Liu, J.; Karanth, S.; Pope, C.; Toxicology 2006, 227, 173.

147. Nallapaneni, A.; Liu, J.; Karanth, S.; Pope, C.; Neurotoxicology 2008, 29,1037.

148. Baireddy, P.; Liu, J.; Hinsdale, M.; Pope, C.; Toxicol. Appl. Pharmacol. 2011, 256, 324.

149. Long, J. Z.; Li, W.; Booker, L.; Burston, J. J.; Kinsey, S. G.; Schlosburg, J. E.; Pavón, F. J.; Serrano, A. M.; Selley, D. E.; Parsons, L. H.; Lichtman, A. H.; Cravatt, B. F.; Nat. Chem. Biol. 2009, $5,37$.

150. McDaniel, K. L.; Moser, V. C.; Neurotoxicol. Teratol. 2004, 26, 407.

151. Nomura, D. K.; Leung, D., Chiang, K. P.; Quistad, G. B.; Cravatt, B. F.; Casida, J. E.; Proc. Natl. Acad. Sci. U. S. A. 2005, 102,6195 .

152. Pope, C. N. In Toxicology of Organophosphate and Carbamate Compounds; Gupta, R. C., ed.; Academic Press: San Diego, 2006, ch. 20. 
153. Nomura, D. K.; Blankman, J. L.; Simon, G. M.; Fujioka, K.; Issa, R. S.; Ward, A. M.; Cravatt, B. F.; Casida, J. E.; Nat. Chem. Biol. 2008, 4, 373.

154. Nomura, D. K.; Durkin, K. A.; Chiang, K. P.; Quistad, G. B.; Cravatt, B. F.; Casida, J. E.; Chem. Res. Toxicol. 2006, 9, 1142.

155. Long, J. Z.; Cravatt, B. F.; Chem. Rev. 2011, 111, 6022.

156. Vilanova, E.; Barril, J.; Carrera, V.; Pellin, M. C.; J. Neurochem. 1990, 55, 1258.

157. Vilanova, E.; Barril, J.; Carrera, V.; Chem.-Biol. Interact. 1993, 3,369 .

158. Vilanova, E.; Escudero, M. A.; Barril, J.; Chem.-Biol. Interact. 1999, 119, 525.

159. Estévez, J.; García-Pérez, A.; Barril, J.; Vilanova, E.; Chem. Res. Toxicol. 2011, 24, 135.

160. Estévez, J.; García-Pérez, A. G.; Barril, J.; Pellín, M.; Vilanova, E.; Toxicol. Lett. 2004, 151, 171.

161. Liu, Y.; Patricelli, M. P.; Cravatt, B. F.; Proc. Natl. Acad. Sci. U. S. A. 1999, 96, 14694.

162. Dijkstra, H. P.; Sprong, H.; Aerts, B. N.; Kruithof, C. A.; Egmond, M. R.; Klein, G., R. J.; Org. Biomol. Chem. 2008, 6, 523.
163. Kidd, D.; Liu, Y.; Cravatt, B. F.; Biochemistry 2001, 40, 4005.

164. Estévez, J.; Mangas, I.; Sogorb, M. Á.; Vilanova, E.; Chem.-Biol. Interact. 2013, 203, 245.

165. Mangas, I.; Vilanova, E.; Benabent, M.; Estévez, J.; Toxicol. Lett. 2014, 225, 167.

166. Mangas, I.; Taylor, P.; Ghassemian, M.; Candela, H.; Vilanova, E.; Estévez, J.; Arch. Toxicol., in press, DOI: 10.1007/s00204016-1670-6.

167. Mangas, I.; Vilanova, E.; Estévez, J.; Arch. Toxicol. 2014, 88, 355.

168. Mangas, I.; Vilanova, E.; Estévez, J.; Toxicology 2012, $297,17$.

169. Mangas, I.; Vilanova, E.; Estévez, J.; Toxicol. Appl. Pharmacol. 2011, 256, 360.

170. Lockdridge, O.; Schopfer, L. M. In Toxicology of Organophosphate and Carbamate Compounds; Gupta, R. C., ed.; Academic Press: San Diego, 2006, ch. 48.

Submitted: January 16, 2016

Published online: March 21, 2016 